\title{
Exploration of Newer Possibilities to the Synthesis of Diazepine and Quinoline Carboxylic Acid Derivatives
}

\author{
Vatsala Soni, Meenakshi Sharma, Anshu Agarwal, and Dharma Kishore \\ Department of Chemistry, Banasthali University, Banasthali, Jaipur 304022, India \\ Correspondence should be addressed to Vatsala Soni; soni.vatsala@gmail.com
}

Received 3 February 2012; Revised 23 June 2012; Accepted 9 July 2012

Academic Editor: Casimiro Mantell

Copyright (C) 2013 Vatsala Soni et al. This is an open access article distributed under the Creative Commons Attribution License, which permits unrestricted use, distribution, and reproduction in any medium, provided the original work is properly cited.

\begin{abstract}
Heterocyclic systems containing benzothiazoles, carbazole (and azacarbazole) moieties have attracted the attention of chemists owing to these nuclei having been identified in the literature as most promising pharmacophores in drug design and synthesis. Based on these observations, it could be anticipated that incorporation of the bioactive azepine moiety and quinoline moiety into the molecular framework of benzothiazoles fused to carbazole (and azacarbazoles) could produce interesting series of compounds 9-12 with enhanced biological activities, whose structure was unequivocally established from its microanalyses and spectral data.
\end{abstract}

\section{Introduction}

The search of compound libraries comprising of small molecules, with potential biological activities is a major focus of research in the area of chemical biology and medicinal chemistry. Therefore, developments of efficient methodologies to access small molecules of medicinal utility are of special interest. Heterocyclic compounds are organic compounds containing at least one atom of carbon, and at least one element other than carbon, such as sulfur, oxygen, or nitrogen within a ring structure. Heterocyclic compounds are very widely distributed in nature and are essential to life in various ways. Benzothiazole is a heterocyclic compound, weak base, having varied biological activities and still of great scientific interest now a days. They are widely found in bioorganic and medicinal chemistry with application in drug discovery. Benzothiazole moieties are part of compounds showing numerous biological activities [1-12]. In the 1950s, a number of 2-aminobenzothiazoles were intensively studied, as the 2-amino benzothiazole scaffold is one of privileged structures in medicinal chemistry $[13,14]$ and reported cytotoxic on cancer cells [14].

Condensed heterocyclic systems containing thiazole, carbazole, azacarbazole, azepine, and quinoline [15-17] nuclei have attracted the attention of chemists, on account of the significant medicinal properties associated with them. In view of the prodigious range of activities of these compounds, it was considered worthwhile in the present work to undertake investigation on the synthesis of condensed nitrogen-sulfur heterocyclic systems containing above nuclei fused to the benzothiazole framework. It was proposed that synthesis of these condensed heterocyclic systems and evaluation of their biological properties would provide a rational approach to the study of structure activity relationship of these molecules.

Carbazoles and azacarbazoles (including pyridocarbazoles) show impressive cytotoxic activity and form interesting targets in synthesis since such structures have potential for the development of anticancer drugs [18-20]. Quinoline carboxylic acids have recently emerged as one of the potent materials useful as potential anti-HIV agents $[21,22]$. Potent anti-HIV activity has also been observed in compounds containing diazepine and benzo- (pyrido-) fused diazepine nucleus. Greatly encouraged by the bioactive profiles of these heterocyclic scaffolds, we intended to develop the bioactive molecules, which incorporated the structural features of these materials in a single molecular framework on the premise that their presence in tandem could contribute significantly to the biological activity in the resulting materials by providing an additive affect on the overall potency of the molecules. Herein, we report the study projected towards the development of diazepine and quinoline carboxylic acid 
substituted analogues of benzothiazole-condensed oxocarbazole and oxoazacarbazole derivatives of medicinal interest.

\section{Experimental Section}

Melting points were determined in an open-glass capillary and are uncorrected. The purity of compounds were checked by TLC on silica gel $(G)$ plates. The IR spectra were recorded on CE Schimadzu FTIR-8400S. ${ }^{1} \mathrm{H}$ NMR spectra were recorded in $\mathrm{CDCl}_{3} / \mathrm{DMSO}-\mathrm{d} 6$ as solvent on AVANCE II 400 (Bruker) spectrometer using TMS as internal reference and values are expressesd in $\delta$ ppm. Mass spectra were recorded in micromass Q-T of micro.

2.1. Preparation of $\mathrm{N}$-(6-Nitro-1,3-benzothiazol-2-yl)-acetamide (2). 2-Amino-6-nitro benzothiazole (1), 6.904 g, $0.02 \mathrm{~mol}$ ) was added in a mixture of pyridine and acetone $(1: 8)$ and were refluxed for half an hour. (Compound $\mathbf{1}$ is insoluble in water hence acetone was used, reaction gave better yield when performed with base pyridine). After that, acetic anhydride $(10 \mathrm{~mL})$ was added, and the contents were refluxed on water bath for 2 hours, from which whitecotton-like needles settled on cooling. The crystals were washed with dil. $\mathrm{HCl}$ and filtered. The recrystallization from methanol gave N-(6-nitro-1,3-benzothiazol-2yl)-acetamide (2). [5.234 g, yield 76\%, m.p. $290-92^{\circ} \mathrm{C}$ ].

2.2. Preparation of N-(6-Aminobenzothiazole-2-yl)-acetamide (3). Compound 2 (2.654 g, $0.0112 \mathrm{~mol})$ in methanol $(25 \mathrm{~mL})$ and conc. $\mathrm{HCl}(9 \mathrm{~mL})$ were taken in $250 \mathrm{~mL}$ round bottom flask, and the mixture was heated on water bath (a bowl with water was put on a magnetic stirrer having temperature regulator, and then $\mathrm{RBF}$ was set onto it with a tiny magnet bar (but stirring was not started), and temperature was set at $\left.80^{\circ} \mathrm{C}\right)$. To it iron powder $(0.244 \mathrm{~g}, 0.044 \mathrm{~mol})$ was added pinch by pinch for an hour with continuous stirring (with magnetic bar). The reaction mixture was further refluxed for $1 \mathrm{~h}$ and then filtered hot. The filtrate was neutralized with aqueous ammonia (50\%) until the dark-brown solid has completely separated out. The organic part was extracted with ethyl acetate. Evaporation of the solvent under reduced pressure gave the crude mass which was recrystallized from ethanol to give fine dark-brown powder 3. [0.623 g, yield 68\%, m.p. $185-87^{\circ} \mathrm{C}$; IR $(\mathrm{KBr}) \mathrm{cm}^{-1}: 3540 \& 3500\left[\mathrm{NH}_{2}\right], 3260$ [N-H str.], 3080 [C-H (aro.) str.], 2920, $2850\left[\mathrm{CH}_{3}\right.$ str.], 1670 [C=O str.], 1600-1470 [C=C \& C=N str.], $1375\left[\mathrm{CH}_{3}\right.$ bend.], 1220 [C-N str.], 800 [=CH (aro.) bend.]; ${ }^{1} \mathrm{H}$ NMR $(400 \mathrm{MHz}$, $\mathrm{CDCl}_{3}$ ) $\delta$ ppm: $12.40[\mathrm{~s}, 1 \mathrm{H}, \mathrm{NHCO}], 7.52$ [d, 1H, ArH], 7.02 [s, 1H, ArH] 6.77 [d, 1H, ArH], 5.37 [s, 2H, $\mathrm{NH}_{2}$ ], 2.09 [s, $3 \mathrm{H}, \mathrm{COCH}_{3}$ ]; MS: $m / z: 237.24$ (30\%); Anal. Calcd./found for $\mathrm{C}_{9} \mathrm{H}_{7} \mathrm{~N}_{3} \mathrm{O}_{3} \mathrm{~S}: \mathrm{C}: 45.57 / 45.01, \mathrm{H}: 2.97 / 2.46, \mathrm{~N}: 17.71 / 17.23$, O: 20.23/19.87, S: 13.52/13.01.

2.3. Preparation of 2-(Hydroxymethylidine)cyclohexanone (5). A mixture of sodium ethoxide $(5.0 \mathrm{~g})$, redistilled cyclohexanone $(23.0 \mathrm{~mL})$, ethyl formate $(27.0 \mathrm{~mL})$, and dry ether $(440 \mathrm{~mL})$ were taken in 1 liter round-bottomed flask. The reaction was initiated by the addition of $2.0 \mathrm{~mL}$ of ethyl alcohol to the stirred mixture, which was then placed in cold water bath. Stirring was continued for $6 \mathrm{hrs}$. After standing the mixture overnight, ethyl alcohol $(6.0 \mathrm{~mL})$ was added, and the mixture was stirred for an additional hour. After the addition of water $(45 \mathrm{~mL})$, the mixture was shaken in a separatory funnel. 2-Hydroxymethylidine cyclohexanone (5) was obtained from the evaporation of the solvent after giving the washing with water (it was used in the next step without further purification).

2.4. Preparation of 1-Benzyl-3-(hydroxymethylidine)piperidin-4-one (6). The procedure described above was used in the preparation of $\mathbf{6}$. Stirring a solution of 1-benzyl4-piperidone $(1.9 \mathrm{~g})$, ethyl formate $(1.0 \mathrm{~mL})$, and sodium ethoxide $(0.072 \mathrm{~g})$ in dry ether $(10 \mathrm{~mL})$ for $1 \mathrm{~h}$ afforded 3-(hydroxymethylidine)piperidin-4-one, which was used in next step without further purification.

\subsection{Preparation of $\mathrm{N}$-(6-Oxo-6,7,8,9-tetrahydro-5H-thia- zolo[5,4-b]carbazole-2yl)acetamide (7)}

2.5.1. Preparation of Hydrazone. A solution of N-(6aminobenzothiazol-2-yl)-acetamide $(3,1.243 \mathrm{~g}, 6.0 \mathrm{mmol})$ in aqueous hydrochloric acid $(3.5 \mathrm{~mL}$ conc. $\mathrm{HCl}$ in $7 \mathrm{~mL}$ water) was treated with cold saturated solution of sodium nitrite $(1.31 \mathrm{~g}$ in $3.0 \mathrm{~mL}$ water), while the temperature was kept at 0 to $5^{\circ} \mathrm{C}$. The solution was kept aside for 10 minutes. It was then added portionwise to an ice-cold mixture containing 2-(hydroxymethylidine)cyclohexanone $(5,0.756 \mathrm{~g}, 6.0 \mathrm{mmol})$, sodium acetate trihydrate $(3.33 \mathrm{~g})$, methanol $(20 \mathrm{~mL})$, and water $(11 \mathrm{~mL})$ over a period of $0.5 \mathrm{hr}$, with stirring. The content was allowed to stand for further $0.5 \mathrm{hrs}$ and the resulting solid mass was filtered, washed with water, dried, and recrystallized from ethanol to give hydrazone [1.19g, yield 62\%] (it was used for cyclisation in next step).

2.5.2. Cyclisation of Hydrazone. A solution of hydrazone $\left(\mathrm{X}=\mathrm{CH}_{2}\right)(2.404 \mathrm{~g}, 0.0076$ mole $)$ in a mixture of acetic acid $(20.0 \mathrm{~mL})$ and hydrochloride acid $(5.0 \mathrm{~mL})$ was refluxed in an oil-bath preheated to $125-130^{\circ} \mathrm{C}$ for $0.5 \mathrm{hr}$. The contents were then cooled and poured into cold water with stirring. The separated brown solid (7) was purified by passing through a column of silica gel using $50 \%$ benzene in petroleum ether as eluant to give 7 . [1.59 g, yield $69 \%$, m.p. $210-12^{\circ} \mathrm{C}$ ], IR $(\mathrm{KBr}) \mathrm{cm}^{-1}: 3400$ [N-H str.(pyrrole)], 3250 [N-H str.], 3140 [C-H str. (Aro.)], 2990, $2860\left[\mathrm{CH}_{3}\right.$ str.] 1715, $1660[\mathrm{C}=\mathrm{O}$ str.], 1610-1470 [C=C \& C=N str.], 1370 [ $\mathrm{CH}_{3}$ bend.], 1180 [C-N str.], 880 [=CH (aro.) bend.]; ${ }^{1} \mathrm{H}$ NMR $(400 \mathrm{MHz}$, $\left.\mathrm{CDCl}_{3}\right) \delta$ ppm: 12.44 [s, 1H, NHCO], 11.93 [s, 1H, pyrrole], 8.09-8.19 [s, 1H, ArH], 7.75 [s, 1H, ArH], 2.96-2.99 [t, 2H, $\mathrm{CH}_{2}$ ], 2.56-2.59 [t, 2H, $\left.\mathrm{CH}_{2}\right], 2.13-2.20\left[\mathrm{~m}, 2 \mathrm{H}, \mathrm{CH}_{2}\right][\mathrm{J}=$ $2.1 \mathrm{~Hz}$ ], 2.06 [s, 3H, $\mathrm{COCH}_{3}$ ]; MS: $\mathrm{m} / z: 299.5$ (10.4\%); Anal. Calcd./found for $\mathrm{C}_{15} \mathrm{H}_{13} \mathrm{~N}_{3} \mathrm{O}_{2} \mathrm{~S}$ : C: 60.18/59.77, $\mathrm{H}$ : 4.38/3.67, $\mathrm{N}: 14.04 / 13.34$, O: $10.69 / 10.12$, S: $10.71 / 10.33$. 


\subsection{Preparation of N-(5-Benzyl-8-oxo-6,7,8,9-tetrahydro-5H- pyrido[3,2-b]thiazolo[4,5-f]indol-2-yl)acetamide (8)}

2.6.1. Preparation of Hydrazone. A solution of $\mathrm{N}-(6-$ aminobenzothiazol-2-yl)-acetamide (3) $(1.243 \mathrm{~g}, 6.0 \mathrm{mmol})$ in aqueous hydrochloric acid $(3.5 \mathrm{~mL}$ conc. $\mathrm{HCl}$ in $7.0 \mathrm{~mL}$ water) was treated with cold saturated solution of sodium nitrite $(1.31 \mathrm{~g}$ in $3.0 \mathrm{~mL}$ water) while the temperature was kept from 0 to $5^{\circ} \mathrm{C}$. The solution was kept aside for 10 minutes. It was then added portionwise to an ice-cold mixture containing 3-(hydroxymethylidine)piperidin-4-one $(6,1.303 \mathrm{~g}, 6.0 \mathrm{mmol})$, sodium acetate trihydrate $(3.33 \mathrm{~g})$, methanol $(20 \mathrm{~mL})$ and water $(11 \mathrm{~mL})$ over a period of $0.5 \mathrm{hr}$ with stirring. The contents were allowed to stand for further $0.5 \mathrm{hr}$, and the resulting solid mass was filtered, washed with water, dried, and recrystallized from ethanol to give hydrazone [1.22 g, yield 49.8\%] (it was used for cyclisation in next step).

2.6.2. Cyclisation of Hydrazone. A solution of hydrazone $\left(\mathrm{X}=\mathrm{N}-\mathrm{CH}_{2}-\mathrm{C}_{6} \mathrm{H}_{5}\right)(3.09 \mathrm{~g}, 0.0076 \mathrm{~mol})$ in a mixture of acetic acid $(20.0 \mathrm{~mL})$ and hydrochloride acid $(5.0 \mathrm{~mL})$ was refluxed in an oil bath preheated to $125-130^{\circ} \mathrm{C}$ for $0.5 \mathrm{hr}$. The contents were then cooled and poured into cold water with stirring. The separated brown solid (8) was purified by passing through a column of silica gel using $50 \%$ benzene in petroleum ether as eluant to give 8 . [2.09 g, yield 70\%, m.p. $260-62^{\circ} \mathrm{C}$ ], IR (KBr) cm ${ }^{-1}: 3420$ [N-H str.(pyrrole)], 3300 [N-H str.], 3080 [C-H str. (Aro.)], 2980, $2890\left[\mathrm{CH}_{3}\right.$ str.], 2926, 2853 [ $-\mathrm{CH}_{2}-$ str.] 1720,1650 [C=O str.], 1600-1480 [C=C \& C=N str.], 1465 [- $-\mathrm{CH}_{2}-$ bend.], $1375\left[-\mathrm{CH}_{3}\right.$ bend.], 1250 [CN str.], 900 [=CH (aro.) bend.]; ${ }^{1} \mathrm{H}$ NMR $(400 \mathrm{MHz}$, $\left.\mathrm{CDCl}_{3}\right) \delta$ ppm: 12.50 [s, $\left.1 \mathrm{H}, \mathrm{NHCO}\right], 11.73$ [s, $1 \mathrm{H}$, pyrrole], $8.19[\mathrm{~s}, 1 \mathrm{H}, \mathrm{ArH}], 7.57[\mathrm{~s}, 1 \mathrm{H}, \mathrm{ArH}], 7.33-7.23[\mathrm{~m}, 5 \mathrm{H}, \mathrm{ArH}]$ $[J=3.7 \mathrm{~Hz}], 4.52\left[\mathrm{~s}, 2 \mathrm{H}, \mathrm{CH}_{2}\right], 3.59\left[\mathrm{t}, 2 \mathrm{H}, \mathrm{CH}_{2}\right], 2.53[\mathrm{t}, 2 \mathrm{H}$, $\mathrm{CH}_{2}$ ], 2.05 [s, 3H, $\mathrm{COCH}_{3}$ ]; MS: m/z: 396.35 (23.6\%); Anal. Calcd./found for $\mathrm{C}_{21} \mathrm{H}_{24} \mathrm{~N}_{4} \mathrm{O}_{2} \mathrm{~S}: \mathrm{C}: 63.61 / 63.09, \mathrm{H}: 6.10 / 5.34$, $\mathrm{N}: 14.13 / 13.78$, O: 8.07/7.85, S: 8.09/7.65.

2.7. Preparation of $\mathrm{N}-(6-\mathrm{O} x \mathrm{x}-5,6,7,8,9,10$-hexahydroazepino[3,4-b]thiazolo[4,5-f]indol-2-yl)acetamide (9). 2,4,6Trichloro-[1,3,5]triazine $(1.84 \mathrm{~g}, 10.0 \mathrm{mmol})$ was added to DMF $(2 \mathrm{~mL})$ and maintained at $25^{\circ} \mathrm{C}$. After formation of white solid, the reaction was monitored (TLC) until complete disappearance of TCT. Then N-(6-oxo-6,7,8,9tetrahydro-5H-thiazolo[5,4-b]carbazole-2yl)acetamide (7) $(2.99 \mathrm{~g}, 10.0 \mathrm{mmol})$ in DMF $(15 \mathrm{~mL})$ was added. After the addition, the mixture was stirred at room temperature and monitored (TLC) until completion of reaction (20 hours). Water $(20 \mathrm{~mL})$ was added, then the organic phase washed with $15 \mathrm{~mL}$ of a saturated solution of $\mathrm{Na}_{2} \mathrm{CO}_{3}$, followed by $1 \mathrm{~N} \mathrm{HCl}$ and brine. The organic layer was dried over the sodium sulphate. Evaporation of solvent gave 9. [2.43 g, yield $77 \%$, m.p. $\left.260-62^{\circ} \mathrm{C}\right]$, IR $(\mathrm{KBr}) \mathrm{cm}^{-1}: 3510[\mathrm{~N}-\mathrm{H}$ str.(pyrrole)], 3350 [N-H str.(NHCO)], $3010[\mathrm{C}-\mathrm{H}$ str. (Aro.)], 2950 [C-H str. $\mathrm{CH}_{3}$ ] 1690, 1670 [C=O str.], 1510 [C=C str.], 1490 [C=N str.], $1350\left[\mathrm{CH}_{3}\right.$ bend.], 1090 [C-N str.], 800 [o-mono subs.]; ${ }^{1} \mathrm{H}$ NMR $\left(400 \mathrm{MHz}, \mathrm{CDCl}_{3}\right) \delta$ ppm: 12.34 [s, 1H, NHCO], 11.32 [s, 1H, Pyrrole], 8.33 [s, $1 \mathrm{H}, \mathrm{ArH}], 7.90[\mathrm{~s}, 1 \mathrm{H}, \mathrm{ArH}], 7.49[\mathrm{~s}, 1 \mathrm{H}, \mathrm{NH}], 2.90-2.84$ [t, $\left.2 \mathrm{H}, \mathrm{CH}_{2}\right], 2.74-2.71\left[\mathrm{t}, 2 \mathrm{H}, \mathrm{CH}_{2}\right], 2.08\left[\mathrm{~s}, 3 \mathrm{H}, \mathrm{COCH}_{3}\right]$, $1.89-1.74\left[\mathrm{~m}, 2 \mathrm{H}, \mathrm{CH}_{2}\right][J=4.9 \mathrm{~Hz}] ; \mathrm{MS}: m / z: 314.5$ [12.4\%]; Anal. Calcd./found for $\mathrm{C}_{15} \mathrm{H}_{14} \mathrm{~N}_{4} \mathrm{O}_{2} \mathrm{~S}: 314.36$, C: 57.31/56.79, H: 4.49/4.09, N: 17.82/17.19, O: 10.18/9.66, S: $10.20 / 9.75$.

Similarly N-(10-benzyl-6-oxo-5,6,7,8,9,10-hexahydro[1,4]diazepine[6,5-b]thiazolo[4,5-f]indol-2-yl)acetamide

(10) was prepared from N-(5-benzyl-8-oxo-6,7,8,9-tetrahydro-5H-pyrido[3,2-b]thiazolo[4,5-f]indol-2-yl)acetamide (8) $(3.904 \mathrm{~g})$ by the above procedure. [2.99 g, yield $74 \%$, m.p. $269-71^{\circ} \mathrm{C}$ ], IR (KBr) $\mathrm{cm}^{-1}: 3460$ [N-H str.(pyrrole)], 3300 [N-H str.(NHCO)], 3070 [C-H str. (Aro.)], 2990 $\left[\mathrm{C}-\mathrm{H}\right.$ str. $\left.\mathrm{CH}_{3}\right], 2860\left[\mathrm{C}-\mathrm{H}\right.$ str. $\left.\mathrm{CH}_{2}\right], 1780,1650[\mathrm{C}=\mathrm{O}]$, 1560 [C=C str.], 1460 [C=N str.], $1410\left[\mathrm{CH}_{2}\right.$ bend.], 1375 $\left[\mathrm{CH}_{3}\right.$ bend.], 1270 [C-N str.], 825 [o-mono subs.]; ${ }^{1} \mathrm{H}$ NMR $\left(400 \mathrm{MHz}, \mathrm{CDCl}_{3}\right) \delta$ ppm: $12.33[\mathrm{~s}, 1 \mathrm{H}, \mathrm{NHCO}]$, 11.69 [s, 1H, Pyrrole], 8.95 [s, 1H, ArH], 8.29 [s, 1H, NH], 7.59 [s, 1H, ArH] $7.34-7.19[\mathrm{~m}, 5 \mathrm{H}, \mathrm{ArH}][J=7.2 \mathrm{~Hz}$, $4.79\left[\mathrm{~s}, 2 \mathrm{H}, \mathrm{CH}_{2}\right], 3.35\left[\mathrm{t}, 2 \mathrm{H}, \mathrm{CH}_{2}\right], 3.12\left[\mathrm{t}, 2 \mathrm{H}, \mathrm{CH}_{2}\right]$, 2.02 [s, 3H, $\mathrm{COCH}_{3}$; $\mathrm{MS}: m / z: 405.13$ (13.8\%); Anal. Calcd./found for $\mathrm{C}_{21} \mathrm{H}_{19} \mathrm{~N}_{5} \mathrm{O}_{2} \mathrm{~S}$ : 405.47, C: 62.21/61.87, $\mathrm{H}: 4.72 / 4.22, \quad \mathrm{~N}: 17.27 / 16.78, \quad \mathrm{O}: 7.89 / 7.18, \quad \mathrm{~S}: 7.91 /$ 7.45 .

2.8. Preparation of 10-Acetamido-7,13-dihydro-6H-thiazolo $\left[4^{\prime}, 5^{\prime}: 5,6\right]$ indolo[3,2-c]acridine-5-carboxylic Acid (11). A mixture of isatin $(1.47 \mathrm{~g}, 10.0 \mathrm{mmol})$ and $\mathrm{N}$-(6-oxo-6,7,8,9tetrahydro-5H-thiazolo[5,4-b]carbazole-2yl)acetamide (7) $(2.99 \mathrm{~g}, 10.0 \mathrm{mmol})$ in $50 \%$ aq. EtOH $(0.4 \mathrm{~mL})$ containing $\mathrm{KOH}(0.4 \mathrm{~g})$ was heated under reflux for 20 hours and then diluted with $50 \%$ aq. EtOH to obtain a homogenous mixture. This was filtered and acidified with $\mathrm{AcOH}$, and the precipitate was collected, washed with $30 \%$ aq. EtOH, and recrystallized from $\mathrm{MeOH}$ to give 11. [2.67 g, yield 62\%, m.p. $195-97^{\circ} \mathrm{C}$ ], IR (KBr) cm ${ }^{-1}: 3550$ [O-H str.], 3460 [N-H str.(pyrrole)], 3300 [N-H str.(NHCO)], 3050 [C-H str. (Aro.)], $2960\left[\mathrm{CH}_{3}\right.$ str.], 1810, $1670[\mathrm{C}=\mathrm{O}], 1570$ [C=C str.], 1480 [C=N str.], $1320\left[\mathrm{CH}_{3}\right.$ bend.], 1290 [C-N str.]; ${ }^{1} \mathrm{H}$ NMR $(400 \mathrm{MHz}$, DMSO) $\delta$ ppm: $12.79[\mathrm{~s}, 1 \mathrm{H}, \mathrm{OH}], 12.33[\mathrm{~s}, 1 \mathrm{H}, \mathrm{NHCO}]$, 11.23 [s, 1H, Pyrrole], 8.75 [s, 1H, ArH], 8.15-7.65 [m, 4H, $\mathrm{ArH}][J=8.6 \mathrm{~Hz}], 7.34[\mathrm{~s}, 1 \mathrm{H}, \mathrm{ArH}], 3.03\left[\mathrm{t}, 2 \mathrm{H}, \mathrm{CH}_{2}\right], 2.83$ [t, 2H, $\mathrm{CH}_{2}$ ] 2.03 [s, 3H, $\mathrm{COCH}_{3}$ ]; MS: $m / z: 428.4$ (7.3\%); Anal. Calcd./found for $\mathrm{C}_{23} \mathrm{H}_{16} \mathrm{~N}_{4} \mathrm{O}_{3} \mathrm{~S}$ : C: 64.47/63.89, $\mathrm{H}: 3.76 / 3.12, \mathrm{~N}: 13.08 / 12.88, \mathrm{O}: 11.20 / 10.67, \mathrm{~S}: 7.48 /$ 6.98.

Similarly 10-acetamido-7-benzyl-7,13-dihydro-6H-benzo[b] thiazolo $\left[4^{\prime}, 5^{\prime}: 5,6\right]$ indolo[ $[3,2-\mathrm{h}][1,6]$ naphthyridine-5carboxylic acid (12) was prepared from N-(5-benzyl-8-oxo6,7,8,9-tetrahydro-5H-pyrido[3,2-b]thiazolo[4, 5-f] indol-2yl)acetamide (8) $(3.904 \mathrm{~g})$ by the above procedure. [3.54 g, yield $68 \%$, m.p. $185-87^{\circ} \mathrm{C}$ ], IR $(\mathrm{KBr}) \mathrm{cm}^{-1}: 3530$ [O-H str.], 3490 [N-H str.(pyrrole)], 3350 [N-H str.(NHCO)], 3060 [C-H str. (Aro.)], $2970\left[\mathrm{C}-\mathrm{H}\right.$ str. $\left.\mathrm{CH}_{3}\right], 2870[\mathrm{C}-\mathrm{H}$ str. $\mathrm{CH}_{2}$ ] $, 1820,1680$ [C=O str.], 1600 [C=C str. $\mathrm{ArH}$ ] 1490 [C=N str.], 1400 [ $\mathrm{CH}_{2}$ bend.], $1375\left[\mathrm{CH}_{3}\right.$ bend.], 1050 [C-N str.]; ${ }^{1} \mathrm{H}$ NMR (400 MHz, DMSO) $\delta$ ppm: 12.92 [s, $1 \mathrm{H}, \mathrm{OH}$ ], 
<smiles>COC(=O)Nc1nc2ccc([N+](=O)[O-])cc2s1</smiles>

(1)

(2)

(3)

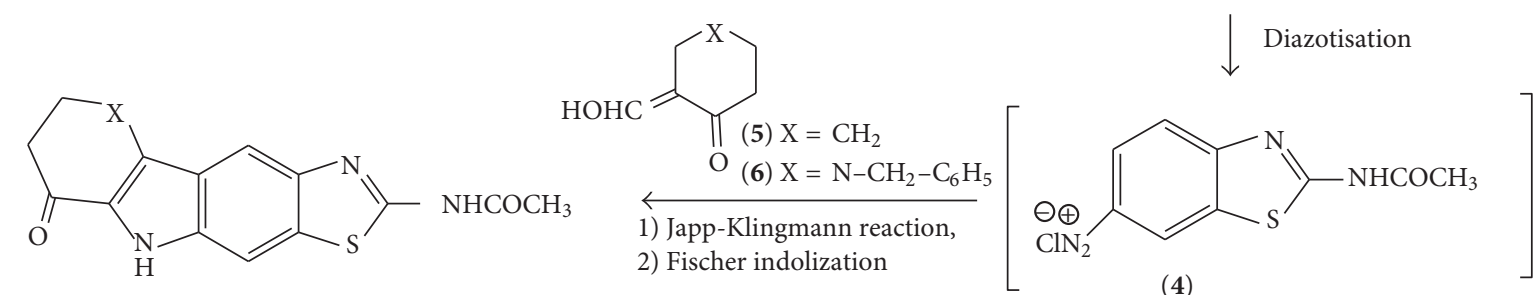

(7) $\mathrm{X}=\mathrm{CH}_{2}$

(8) $\mathrm{X}=\mathrm{N}-\mathrm{CH}_{2}-\mathrm{C}_{6} \mathrm{H}_{5}$<smiles>CC(=O)Nc1nc2ccc([N+]#N)cc2s1</smiles>

(3)

(4)

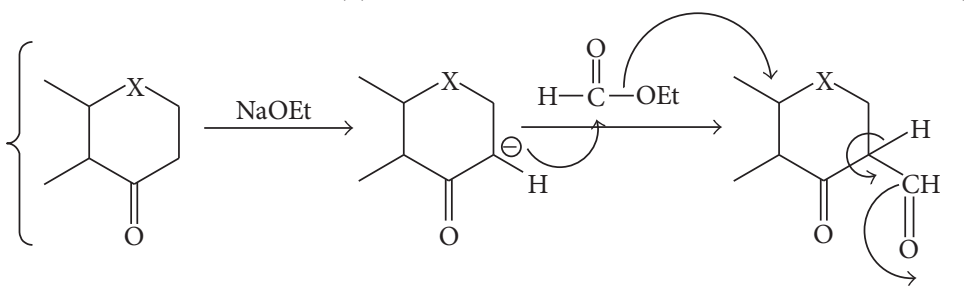

(5) $\mathrm{X}=\mathrm{CH}_{2}$
(6) $\mathrm{X}=\mathrm{N}-\mathrm{CH}_{2}-\mathrm{C}_{6} \mathrm{H}_{5}$<smiles>CCO/C=C1/C[X]C(C)C(C)C1=O</smiles><smiles>[Z19]=[W]=CC=CC</smiles><smiles>CCON(C)C</smiles>

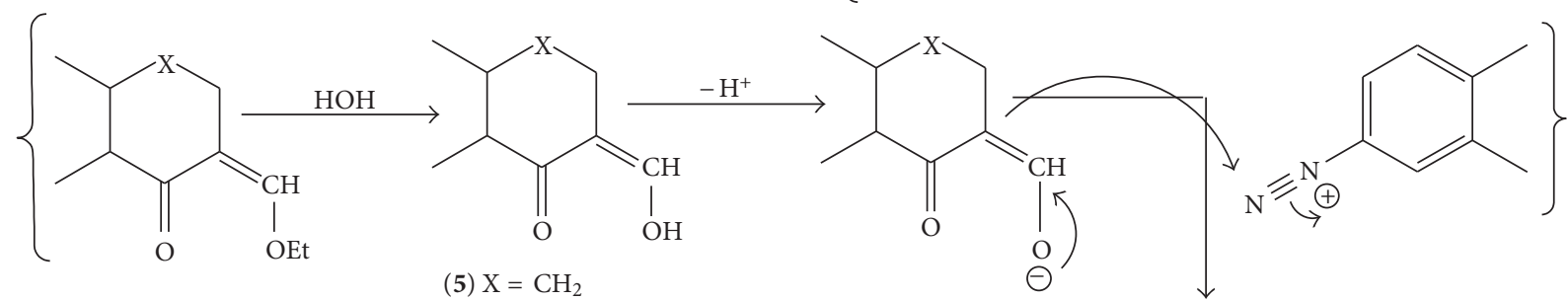

(6) $\mathrm{X}=\mathrm{N}-\mathrm{CH}_{2}-\mathrm{C}_{6} \mathrm{H}_{5}$<smiles>[X]C1CC(=NNc2ccc(C)c(C)c2)C(=O)C(C)C1C</smiles>

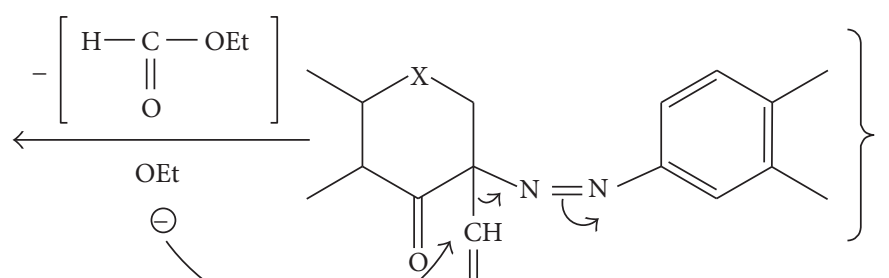

(a)<smiles>[X]C1CC(=NNc2ccc(C)c(C)c2)C(=O)C(C)C1C</smiles>

(c)<smiles>[X]C1=c2[nH]c3cc4sc(NC(C)=O)nc4cc3c2=C1CCCC</smiles>

(7) $\mathrm{X}=\mathrm{CH}_{2}$

(8) $\mathrm{X}=\mathrm{N}-\mathrm{CH}_{2}-\mathrm{C}_{6} \mathrm{H}_{5}$

SCHEME 1 


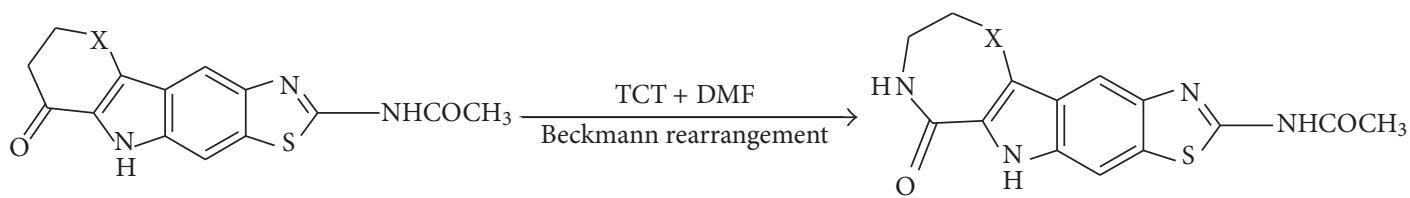

(7) $\mathrm{X}=\mathrm{CH}_{2}$

(8) $\mathrm{X}=\mathrm{N}-\mathrm{CH}_{2}-\mathrm{C}_{6} \mathrm{H}_{5}$

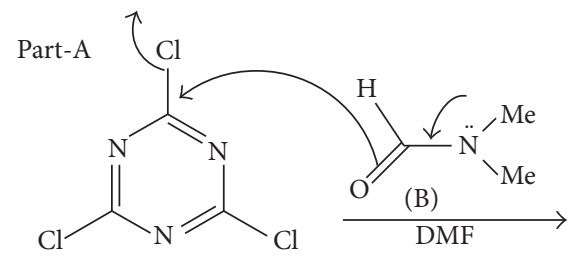

(A)
(9) $\mathrm{X}=\mathrm{CH}_{2}$

(10) $\mathrm{X}=\mathrm{N}-\mathrm{CH}_{2}-\mathrm{C}_{6} \mathrm{H}_{5}$

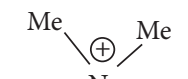<smiles>Clc1ncnc(Cl)n1</smiles>

(C)<smiles>C[N+](C)=CCl</smiles>

(D)

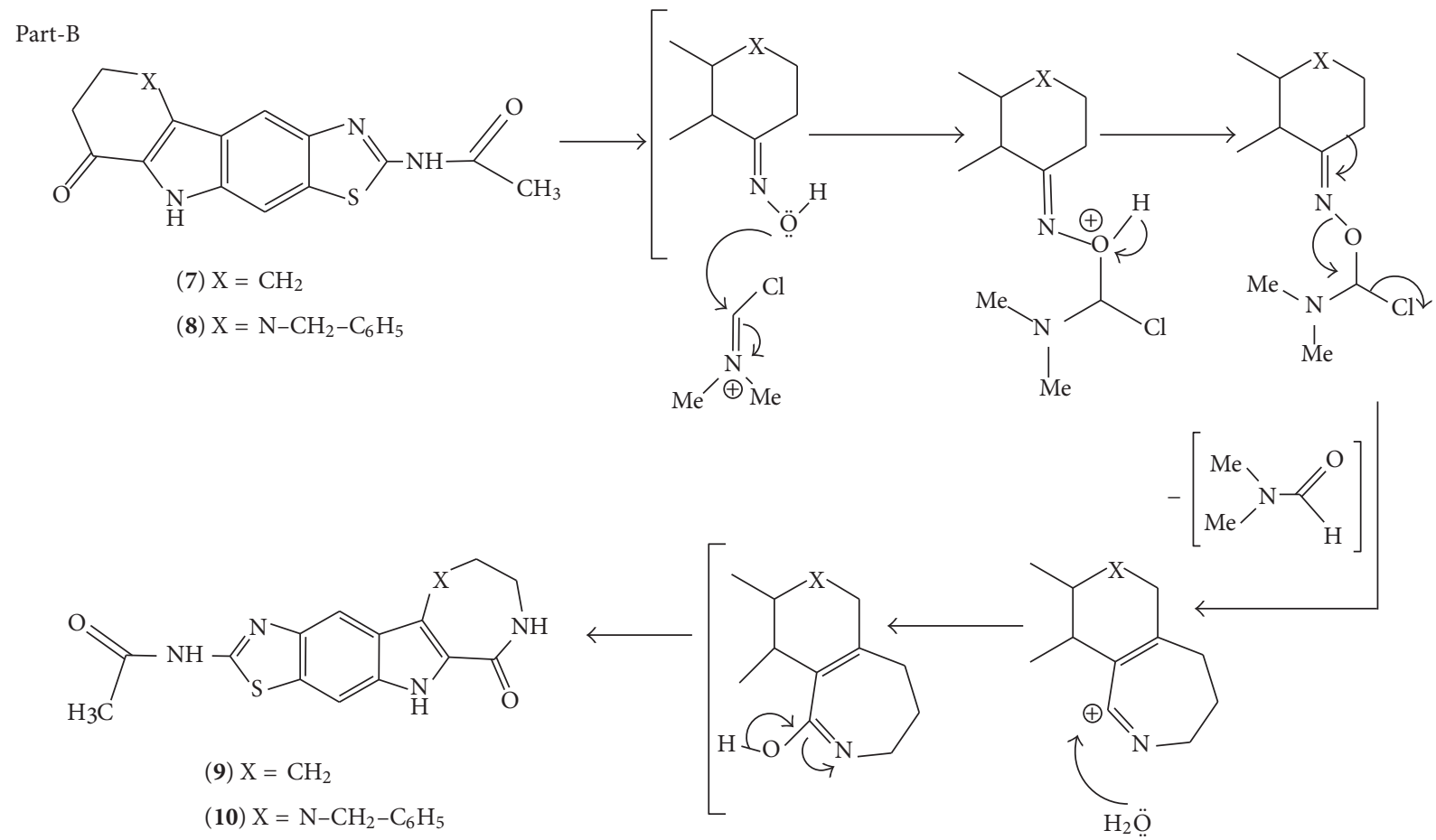

SCHEME 2

12.55 [s, 1H, NHCO], 11.24 [s, 1H, Pyrrole], 8.74 [s, 1H, $\mathrm{ArH}], 8.32-7.99[\mathrm{~m}, 4 \mathrm{H}, \mathrm{ArH}][J=8.2 \mathrm{~Hz}], 7.56[\mathrm{~s}, 1 \mathrm{H}$, $\mathrm{ArH}], 7.32-7.19[\mathrm{~m}, 5 \mathrm{H}, \mathrm{ArH}][J=6.2 \mathrm{~Hz}], 4.79[\mathrm{~s}, 2 \mathrm{H}$, $\mathrm{CH}_{2}$ ] $4.23\left[\mathrm{~s}, 2 \mathrm{H}, \mathrm{CH}_{2}\right], 2.08\left[\mathrm{~s}, 3 \mathrm{H}, \mathrm{COCH}_{3}\right] ; \mathrm{MS}: \mathrm{m} / z$ : 519.5 (22.8\%); Anal. Calcd./found for $\mathrm{C}_{29} \mathrm{H}_{21} \mathrm{~N}_{5} \mathrm{O}_{3} \mathrm{~S}$ : C: 67.04/66.57, H: 4.07/3.78, N: 13.48/13.02, O: 9.24/8.78, S: $6.17 / 5.65$.

\section{Results and Discussion}

Ever since, the potential of 2-amino-6-nitro benzothiazole has been recognized in the literature [23-25] for providing an unprecedented opportunity to a chemist in synthesis; it has remained in the mainstay as the evergreen synthon in the synthesis of a wide variety of six- and seven-membered 
<smiles></smiles>

(7) $\mathrm{X}=\mathrm{CH}_{2}$

(8) $\mathrm{X}=\mathrm{N}-\mathrm{CH}_{2}-\mathrm{C}_{6} \mathrm{H}_{5}$<smiles></smiles>

(11) $\mathrm{X}=\mathrm{CH}_{2}$

(12) $\mathrm{X}=\mathrm{N}-\mathrm{CH}_{2}-\mathrm{C}_{6} \mathrm{H}_{5}$

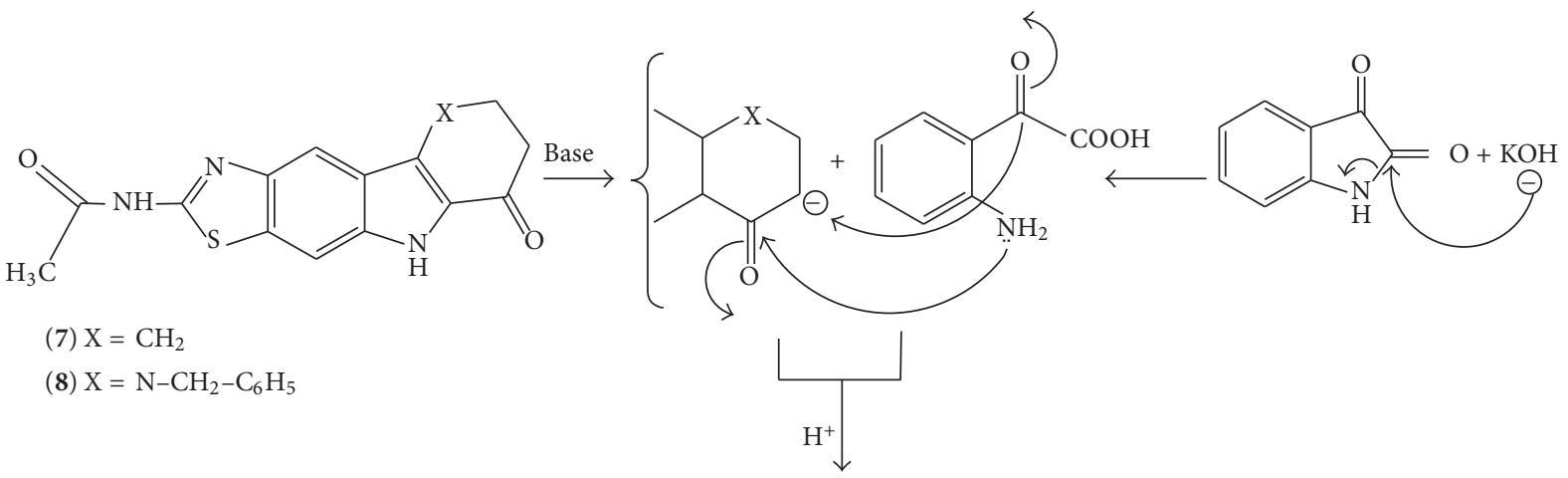

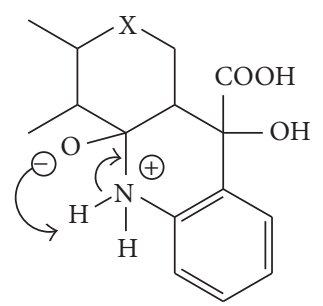

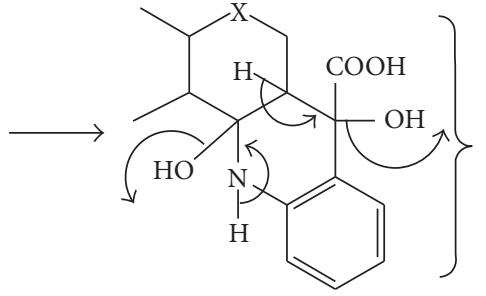<smiles>[X]Cc1c(-c2[nH]c3cc4sc(NC(C)=O)nc4cc3c2[X])nc2ccccc2c1C(=O)O</smiles><smiles>CCC</smiles>

(11) $\mathrm{X}=\mathrm{CH}_{2}$

(12) $\mathrm{X}=\mathrm{N}-\mathrm{CH}_{2}-\mathrm{C}_{6} \mathrm{H}_{5}$

SCHEME 3

heterocyclic rings. In order that our synthetic plan depicted in Scheme 1 using 2-amino-6-nitrobenzothiazole could succeed to form the indicated heterocyclic rings on the carbonyl compounds with adjacent $\mathrm{CH}_{2}$ group, the synthesis had to proceed through the formation of the benzothiazole-fused carbazole and azacarbazole derivatives 7 and 8, respectively. The method reported $[6,26]$ in the literature was adopted for the preparation of N-(6-nitrobenzothiazole-2-yl)-acetamide (2) from 2-amino-6-nitrobenzothiazole (1). The reduction of its nitro group in the subsequent step gave the $\mathrm{N}$-(6aminobenzothiazole-2-yl)-acetamide (3) [27].

It is known from the literature [28] that diazotized arylamines readily condense with 2-(hydroxymethylidine) cyclohexanones under the condition of Japp-Klingernann reaction followed by Fischer indolization to give the tetrahydrocarbazole-4-one derivatives. Using this procedure, the diazotized derivative (4) was condensed with 2-(hydroxymethylidine)cyclohexanones (5) and 3-(hydroxymethylidine)piperidin-4-one (6) (which were prepared [29, 30] in situ from the reaction of cyclohexanone or 4-piperidone with ethylformate and sodium ethoxide) to give 7 and $\mathbf{8}$, respectively (Scheme 1).

Phenyl hydrazone (c) is the key intermediate from which the carbazole and azacarbazole derivatives 7 and 8 have emerged. The formation of phenyl hydrazone is suggested to take place through the sequence of reaction shown in Scheme 1. It is assumed that phenyl hydrazone is formed by the base catalyzed nucleophilic addition of $\mathbf{5}$ on the diazonium salt 
(4) to first generate the species (a), which in the subsequent steps forms (b) by the base catalyzed elimination of the formyl ester. The species (b) accepts a proton from the solvent to produce the hydrazone (c) which in the subsequent step undergoes acid catalyzed Fischer indolization to furnish carbazole and azacarbazole derivatives ( 7 and 8 ), respectively.

Benzothiazole-fused oxocarbazole (and oxoazacarbazole) oximes underwent Beckmann rearrangement in TCTDMF under milder conditions to afford azepine (and 1,5diazepine) derivatives (9 and 10) respectively (Scheme 2).

Benzothiazole condensed oxocarbazole (and oxoazacarbazole) underwent Pfitzinger reaction with isatin to give quinoline carboxylic acid derivatives (11 and 12), respectively (Scheme 3).

\section{Conclusion}

This study was undertaken on this premise that the presence of each scaffold in tandem, with a different mechanism of action, could allow to form materials possibly with new pharmacological profiles with action-strengthening effects and toxicity-lowering effects. In summary, the procedure reported herein allowed an easy preparation of quinoline and azepine derivatives. Application of the methodology depicted in Scheme 1 afforded the desired products in good yield. The method was characterized by short reaction time, mild reaction conditions, nontoxic byproduct, and easy reaction workup. It was worth noting that application of this methodology allowed the preparation of the corresponding heteroring annulated compounds (9-12) directly from (7-8) in one step, in good yield.

\section{Acknowledgment}

Authors are grateful to Head Department of Chemistry of Punjab University (Punjab) for providing the microanalysis and spectral data. Authors are thankful to the Department of Science and Technology (DST) New Delhi (India) for providing financial assistance to Banasthali Centre for Education and Research in Basic Sciences under their Consolidation of University Research for innovation and Excellence in Women University (CURIE) programme.

\section{References}

[1] A. Achson, An Introduction to the Chemistry of Heterocyclic Compounds, Wiley-Intersciences, India, 3rd edition, 2009.

[2] S. Gupta, N. Ajmera, N. Gautam, R. Sharma, and D. Gautam, "Novel synthesis and biological activity study of pyrimido[2,1b] benzothiazoles," Indian Journal of Chemistry B, vol. 48, no. 6 , pp. 853-858, 2009.

[3] R. M. Kumbhare and V. N. Ingle, "Synthesis of novel benzothiozole and benzisoxazole functionalized unsymmetrical alkanes and of there antimicrobial activity," Indian Journal of Chemistry $B$, vol. 48, no. 7, pp. 996-1000, 2009.

[4] Y. Murthi and D. Pathak, "Synthesis and antimicrobial screening of substituted 2-mercaptobenzothiazoles," Journal of Pharmacy Research, vol. 7, no. 3, pp. 153-155, 2008.
[5] B. Rajeeva, N. Srinivasulu, and S. Shantakumar, "Synthesis and antimicrobial activity of some new 2-substituted benzothiazole derivatives," E-Journal of Chemistry, vol. 6, no. 3, pp. 775-779, 2009.

[6] M. Mahran, S. William, F. Ramzy, and A. Sembel, "Synthesis and in vitro evaluation of new benzothiazole derivatives as schistosomicidal agents," Molecules, vol. 12, no. 3, pp. 622-633, 2007.

[7] S. Kini, S. Swain, and A. Gandhi, "Synthesis and evaluation of novel benzothiazole derivatives against human cervical cancer cell lines," Indian Journal of Pharmaceutical Sciences, vol. 69, no. 1, pp. 46-50, 2007.

[8] H. L. K. Stanton, R. Gambari, H. C. Chung, C. O. T. Johny, C. Filly, and S. C. C. Albert, "Synthesis and anti-cancer activity of benzothiazole containing phthalimide on human carcinoma cell lines," Bioorganic \& Medicinal Chemistry, vol. 16, pp. 3626-3631, 2008.

[9] M. Wang, M. Gao, B. Mock et al., "Synthesis of carbon-11 labeled fluorinated 2-arylbenzothiazoles as novel potential PET cancer imaging agents," Bioorganic \& Medicinal Chemistry, vol. 14, no. 24, pp. 8599-8607, 2006.

[10] I. Hutchinson, M. S. Chua, H. L. Browne et al., "Antitumor benzothiazoles. 14. Synthesis and in vitro biological properties of fluorinated 2-(4-aminophenyl)benzothiazoles," Journal of Medicinal Chemistry, vol. 44, no. 9, pp. 1446-1455, 2001.

[11] M. Sreenivasa, E. Jaychand, B. Shivakumar, K. Jayrajkumar, and J. Vijaykumar, "Synthesis of bioactive molecule flurobenzothiazole comprising potent heterocylic moieties for anthelmintic activity," Archives of Pharmaceutical Sciences and Research, vol. 1, no. 2, pp. 150-157, 2009.

[12] S. Pattan, C. Suresh, V. Pujar, V. Reddy, V. Rasal, and B. Koti, "Synthesis and antidiabetic activity of 2-amino [5' (4-sulphonylbenzylidine)-2,4-thiazolidinedione]-7-chloro6-fluorobenzothiazole," Indian Journal of Chemistry B, vol. 44, no. 11, pp. 2404-2408, 2005.

[13] P. Reddy, Y. Lin, and H. Chang, "Synthesis of novel benzothiazole compounds with an extended conjugated system," The Archive for Organic Chemistry, vol. 16, pp. 113-122, 2007.

[14] F. Piscitelli, C. Ballatore, and A. Smith, "Solid phase synthesis of 2-aminobenzothiazoles," Bioorganic \& Medicinal Chemistry Letters, vol. 20, no. 2, pp. 644-648, 2010.

[15] A. Kumar, H. Juniappa, and H. Illa, "A new general method for the synthesis of 1,3-disubstituted-5-cyano-4-methylthaio6-oxo-1,6-dihydropyrano[2,3]-clpyrazoles; using $\alpha$-ketene S,SAcetals," Synthesis, vol. 324, 1976.

[16] S. M. S. Chauhan and H. Junjappa, "Ketene-S,S-acetals-V: the reactions of $\alpha$-keto and $\alpha$-cyanoketene-S,S-acetals with guanidine and thiourea: a new general synthesis of alkoxypyrimidines," Tetrahedron, vol. 32, no. 14, pp. 1779-1787, 1976.

[17] S. M. S. Chauhan and H. Junjappa, "Ketene-S,S,-acetals-VI: synthesis of 3,3-bis-(methylthio)-2-propene-2-alkyl-1-aryl-1-ones and their reaction with guanidine: a novel route for pyrimidine synthesis," Tetrahedron, vol. 32, no. 15, pp. 1911-1916, 1976.

[18] G. Mahata, M. Hayat, F. De-Vessel et al., "Methoxy-9ellipticine-lactata-III: clinical screening and its action in acetate myeloblastic leukemia," Revue Européenne Détudes Cliniques et Biologiques, vol. 15, pp. 541-545, 1970.

[19] L. M. Werbel, M. Angelo, D. W. Fry, and D. F. Worth, "Basically substituted ellipticine analogues as potential antitumor agents," Journal of Medicinal Chemistry, vol. 29, no. 7, pp. 1321-1322, 1986. 
[20] T. L. Ho and S. Y. Hsieh, "Regioselective synthesis of ellipticine," Helvetica Chimica Acta, vol. 89, no. 1, pp. 111-116, 2006.

[21] F. Corelli, Z. Debyser, S. Pasquini et al., "Investigations on the 4quinolone-3-carboxylic acid motif. 1. Synthesis and structureactivity relationship of a class of human immunodeficiency virus type 1 integrase inhibitors," Journal of Medicinal Chemistry, vol. 51, no. 16, pp. 5125-5129, 2008.

[22] S. Singh, G. Anand, S. Ranjit, and V. Vikrant, "A review on different activity of quinolone derivatives," International Journal of Pharmaceutical Research and Development, vol. 3, no. 4, pp. 164-171, 2011.

[23] A. Rana, N. Siddiqui, and S. A. Khan, "Benzothiazoles: a new profile of biological activities," Indian Journal of Pharmaceutical Sciences, vol. 69, no. 1, pp. 10-17, 2007.

[24] J. K. Malik, F. V. Manvi, B. K. Nanjwade, and P. Purohit, "New 2-amino substituted benzothiazoles: a new profile of biological activities," Journal of Pharmacy Research, vol. 2, no. 11, pp. 1687-1690, 2009.

[25] J. K. Malik, F. V. Manvi, B. K. Nanjwade, S. Singh, and P. Purohit, "Review of the 2-amino substituted benzothiazoles: different methods of the synthesis," Der Pharmacia Lettre, vol. 2, no. 1, pp. 347-359, 2010.

[26] S. Naik, G. Bhattacharjya, V. R. Kavala, and B. K. Patel, "Mild and eco-friendly chemoselective acylation of amines in aqueous medium," The Archive for Organic Chemistry, vol. 2004, no. 1, pp. 55-63, 2004.

[27] P. Hrobárik, I. Sigmundová, and P. Zahradník, "Preparation of novel push-pull benzothiazole derivatives with reverse polarity: compounds with potential non-linear optic application," Synthesis, no. 4, pp. 600-604, 2005.

[28] K. J. R. Prasad and C. S. Vijayalakshmi, "Synthesis of 4-methyloxo-tetrahydro carbazoles," Indian Journal of Chemistry B, vol. 33, pp. 481-482, 1994.

[29] D. P. Chakraborty, K. C. Das, and S. P. Basak ; "New synthesis of isomeric methyl carbazoles," Journal of the Indian Chemical Society, vol. 45, p. 84, 1968.

[30] C. Ainsworth, “Indazole," Organic Synthesis, vol. 4, p. 536, 1963. 

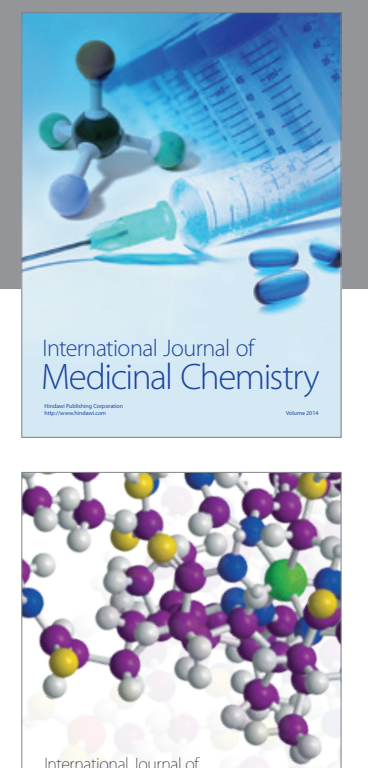

\section{Carbohydrate} Chemistry

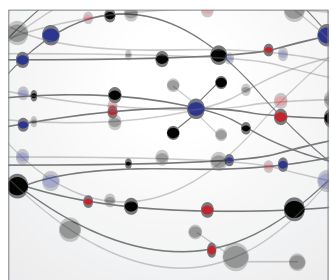

The Scientific World Journal
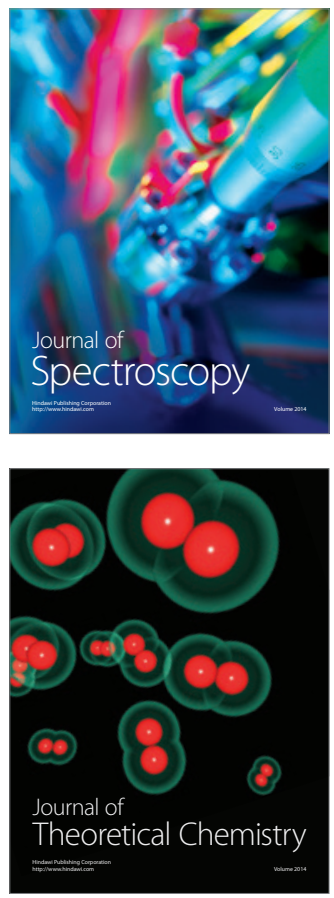
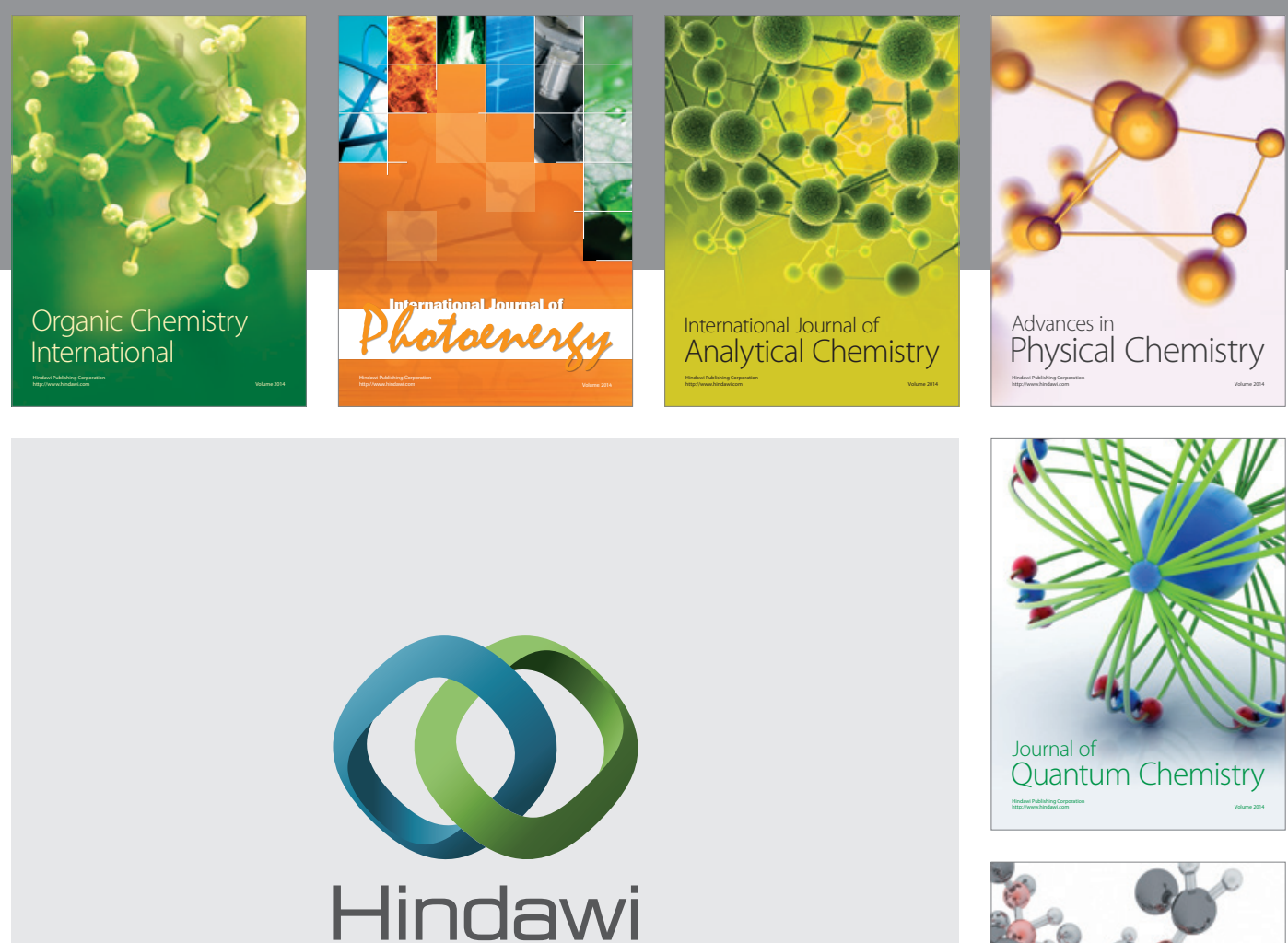

Submit your manuscripts at

http://www.hindawi.com

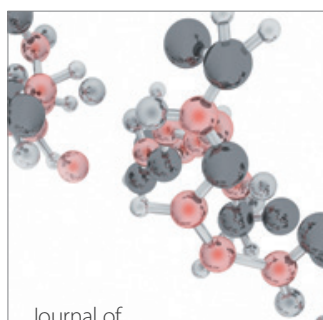

Analytical Methods

in Chemistry

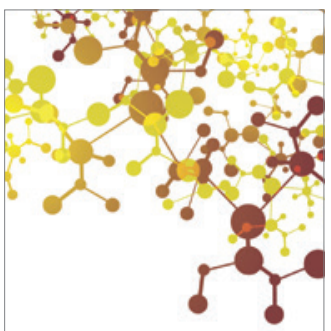

Journal of

Applied Chemistry

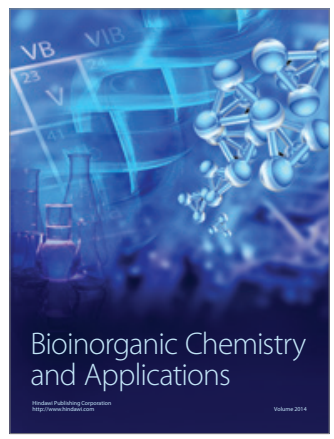

Inorganic Chemistry
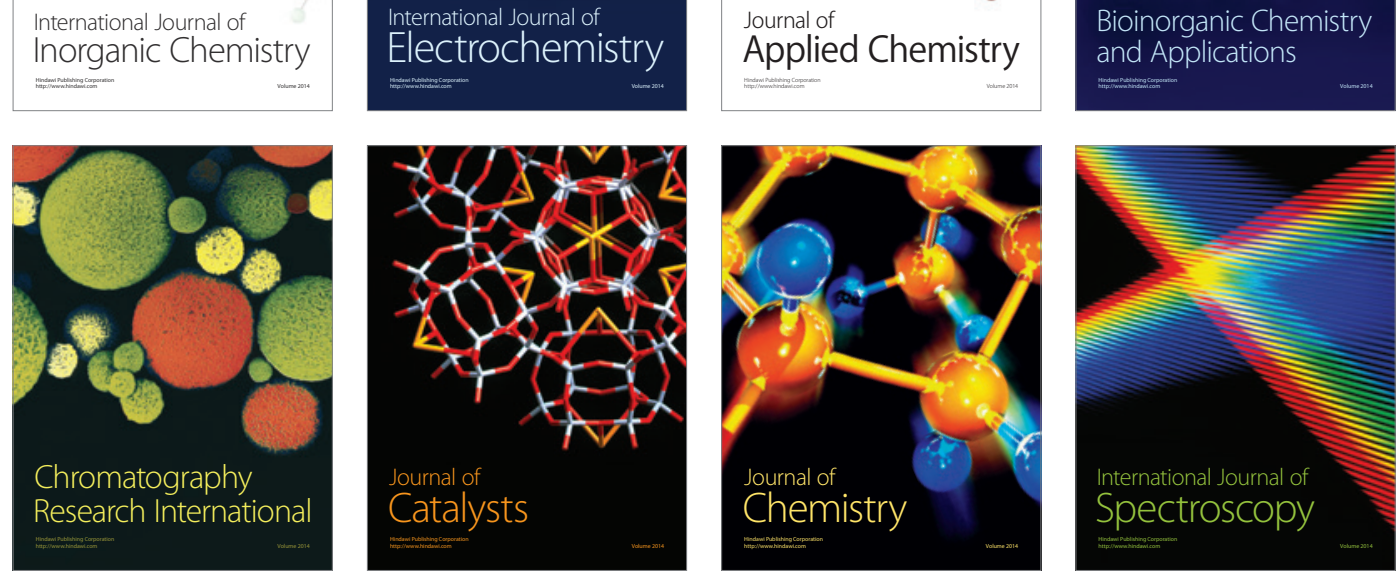